\title{
Erratum to: Breast cancer subtype predictors revisited: from consensus to concordance?
}

\author{
Herman M. J. Sontrop ${ }^{1,2}$, Marcel J. T. Reinders ${ }^{3}$ and Perry D. Moerland ${ }^{4^{*}}$
}

\section{Erratum}

Following the publication of the article in BMC Medical Genomics [1], it was reported that the initials in the author names were incorrectly captured as a part of the surname in the metadata. Please find the correct names below:

Given names: Herman M.J.

Surname: Sontrop

Given names: Marcel J.T.

Surname: Reinders

Given names: Perry D.

Surname: Moerland

We apologize for the inconvenience this may have caused.

\section{Author details}

${ }^{1}$ Molecular Diagnostics Department, Philips Research, High Tech Campus 11, Eindhoven 5656 AE, The Netherlands. ${ }^{2}$ Friss Fraud and Risk Solutions,

Orteliuslaan 15, Utrecht 3528 BA, The Netherlands. ${ }^{3}$ Delft Bioinformatics Lab, Delft University of Technology, Mekelweg 4, Delft 2628 CD, The Netherlands. ${ }^{4}$ Bioinformatics Laboratory, Academic Medical Center, Meibergdreef 9,

Amsterdam $1105 \mathrm{AZ}$, The Netherlands.

Received: 22 June 2016 Accepted: 5 July 2016

Published online: 14 July 2016

\section{Reference}

1. Sontrop et al. Breast cancer subtype predictors revisited: from consensus to concordance? BMC Medical Genomics 2016;9:26.

\footnotetext{
* Correspondence: p.d.moerland@amc.uva.nl

${ }^{4}$ Bioinformatics Laboratory, Academic Medical Center, Meibergdreef 9,

Amsterdam $1105 \mathrm{AZ}$, The Netherlands

Full list of author information is available at the end of the article

Submit your next manuscript to BioMed Central and we will help you at every step:

- We accept pre-submission inquiries

- Our selector tool helps you to find the most relevant journal

- We provide round the clock customer support

- Convenient online submission

- Thorough peer review

- Inclusion in PubMed and all major indexing services

- Maximum visibility for your research

Submit your manuscript at www.biomedcentral.com/submit 